\title{
Impact of Organic Fertilizer and Urea on Grain Yield of Rice Cultivar Giza 178 and Soil Organic Matter Content.
}

\author{
E.S. Naeem, Howida B.I. El-habet and Ayman A.A. \\ Mohamed * \\ Rice Research \& Training Centre, Agricultural Research \\ Centre, Sakha and *Agronomy Department, Faculty of \\ Agriculture, Kafrelsheikh University, Kafrelsheikh, Egypt.
}

$7 W O$ FIELD Experiments were carried out during summer seasons 2007 and 2008 at the experimental farm of Rice Research \& Training Centre, Sakha, Kafrelsheikh, Egypt, to study the effect of organic fertilizers at rates $(0,3,6,9$ ton $/$ fed) as Compost rice straw and inorganic fertilizer (at rate $0,100,150 \mathrm{~kg}$ urea/fed) on rice productivity and soil organic matter (SOM), the experimental design system of layout was randomized complete block with four replications. The highest values of grain and straw yield in both seasons were recorded by the application of 9 tons composted rice straw (CRS) plus $150 \mathrm{~kg}$ urea fed ${ }^{-1}$. but the difference with the grain yield obtained with 6 tons CRS plus $150 \mathrm{~kg}$ urea $\mathrm{fed}^{-1}$ was not significant only in the second season. Also when 6 tons CRS were applied the addition of $100 \mathrm{~kg}$ urea fed ${ }^{-1}$ or $150 \mathrm{~kg}$ urea fed ${ }^{-1}$ had similar effects on yield. There was a slight difference in 1000 grain weight among all treatments. The number of panicle.hill ${ }^{-1}$ increased significantly as fertilizer level increased from $0 \mathrm{~kg} \mathrm{~N}^{-f e d^{-1}}$ without CRS to 9 tons CRS plus $150 \mathrm{~kg}$ urea.fed ${ }^{-1}$. There was a significant difference in panicle length at all treatments of CRS added either separated or combined with urea as compared with the control, Panicle length did not increase with fertilizer level although there was a significant treatment effect (application of CRS, in combination with urea or not) compared to the control. The percentage of soil organic matter in soil increased with increasing the amount of CRS either applied alone or with different levels of urea at all levels compared with the control and soil treated with urea alone. Results showed that organic matter had significant effect on the percentage of soil organic matter and rice grain yield.

We can concluded that combination of Composted rice straw at rate 9 ton/fed with $150 \mathrm{~kg}$ urea/fed increased grain yield with percent 75.64 and $75.35 \%$ over the control (without compost without urea) in 2007 and 2008 respectively and increased the percentage of soil organic matter which gave 2.41 and $2.23 \%$ compared with the control treatment which recorded 1.40 and $1.4 \%$ in both seasons, respectively.

Keywords: Rice (Oryza sativa), Organic fertilizer, Soil organic matter. 
Rice is one of the most important cereal crops in the world as well as in Egypt. Crop residue management and its impact on soil organic matter and nutrient recycling are increasing in importance with the current renewed interest on sustainable soil fertility and crop productivity. Addition of crop residue to soil can increase soil organic matter and considerable amount of $\mathrm{C}$ and $\mathrm{K}$ as well. Among forms of organic residues, incorporated composted rice straw plays an important role in maintaining soil fertility and crop productivity if it returned to the soil. Urea is the major $\mathrm{N}$ fertilizer used for lowland rice fields but it is not effectively utilized by rice because of consistent $\mathrm{N}$ losses, particularly by ammonia volatilization. Integration of composted rice straw and urea will help to reduce the amount of nitrogen fertilizer used besides maintaining the soil fertility which leads to sustainable agriculture. Organic matter content of the soil has been reported to increase due to incorporation of both rice and wheat straw and it was further enhanced when supplemented with fertilizer application (Singha, 2003).

Incorporation of rice straw and addition of straw ash supplemented with fertilizer application significantly increased the crop yield compared to the control (Singha, 2003). The integration use of fertilizer N with organic residue is essential to maximize economic return. Such management practices gave an opportunity to rice farmers to reduce the purchase of inorganic $\mathrm{N}$ fertilizer and therefore to diminish the cost of the crop and improve the farmer income. Therefore, this investigation aims to study the impact of compost rice straw (CRS) in combination with urea on rice yield and its attributes beside soil organic matter situation.

\section{Material and Methods}

A field experiment was conducted using transplanted rice plant (Oryza sativa), Giza178 cultivar during season 2007 and 2008 at farm of Rice Research \& Training Center (RRTC) Kafrelsheikh to fulfill the objectives of the present study, where organic fertilizers at rate $(0,3,6,9$ ton/fed as Compost rice straw (CRS) ) and inorganic fertilizer at rate $(0,100,150 \mathrm{~kg}$ urea/fed). The previous crop was barley; the experimental design system of layout was randomized complete block with four replications, all the amount of composted rice straw was added before flooding and then incorporated into the soil. The date of sowing was first of May. Representative soil samples from $20 \mathrm{~cm}$ depth were taken and subjected to chemical analysis following the standard procedures of Cottenie et al. (1979) and Page et al. (1982). The results showed that the soil was clayey in texture with 1.65 and $1.6 \%$ organic matter, $\mathrm{pH} 8.1$ and 8.19, EC 3 and 3.1, dS.m ${ }^{-1} 13$ and 15ppm P, 305 and 309 ppm K in 2007 and 2008, respectively.

All plots were fertilized with super phosphate $(7 \% \mathrm{P})$ at the rate of $100 \mathrm{~kg}$. $\mathrm{fed}^{-1}$.The randomized complete block design with four replications were used, involving 12 treatments derived from $3 \mathrm{~N}$ - fertilizer $(0,100$ and $150 \mathrm{~kg}$ urea .

Egypt. J. Agron. 33, No. 2 (2011) 
fed-1) combined with composted rice straw at the rate of 0,6 and 9 ton fed $^{-1}$. Urea was added in two split, $2 / 3$ before transplanting and the other $1 / 3$ one month after transplanting. All plots were flooded immediately after the fertilizer application and water head was maintained at 5 to $7 \mathrm{~cm}$ from soil surface throughout the season, three seedlings twenty days old were transplanted / hill. The flooded water was drained from the plots 30 days after transplanting prior to the application methods of the second dose of fertilizer then plots were flooded in the same day. At harvest grain and straw yield and its components were estimated. Grain yield was adjusted to $14 \%$ moisture content. All data collected were subjected to the statistical analysis according to Gomez \& Gomez (1984). Some of this data were also subjected to multiple linear regressions according to this classical formula: $Y=a+b_{1} x_{1}+b_{2} x_{2}+b_{3} x_{3}$ according to Hammad (1995).

\section{Grain and straw yield}

\section{Results and Discussions}

Tables 1 and 2 show the effect of composted rice straw (CRS), urea treatments and their combinations on paddy and straw yield of Giza178 rice cultivar during 2007 and 2008 season. Data reveal that the application of CRS with or without urea produced a significant increase in grains yield. The highest yield of rice grains was obtained with 9 tons CRS plus $150 \mathrm{~kg}$ urea.fed ${ }^{-1}$. This corresponds to an increase of 75.64 and $75.35 \%$ over the control in 2007 and 2008 , respectively. The lowest yield was observed with the control.

TABLE 1. Paddy yield and straw yield $\left(\mathrm{kg.fed}^{-1}\right)$ as affected by the application of CRS (composted rice straw) and urea in 2007 season.

\begin{tabular}{|c|c|c|c|c|c|c|}
\hline Treatments & $\begin{array}{c}\text { Urea } \\
\text { kg. } \text { fed }^{-1}\end{array}$ & $\begin{array}{c}\text { CRS } \\
\text { ton. fed }\end{array}$ & Grains & $\begin{array}{l}\% \text { increase } \\
\text { or decrease }\end{array}$ & Straw & $\begin{array}{l}\% \text { increase } \\
\text { or decrease }\end{array}$ \\
\hline $\mathrm{N}_{0} \mathrm{C}_{0}$ & 0 & 0 & $2835.2 \mathrm{~h}$ & - & $3363.0 \mathrm{i}$ & - \\
\hline $\mathrm{N}_{0} \mathrm{C}_{1}$ & 0 & 3 & $3790.0 \mathrm{f}$ & 33.67 & $4352.5 \mathrm{~h}$ & 29.41 \\
\hline $\mathrm{N}_{0} \mathrm{C}_{2}$ & 0 & 6 & 3918.2 e & 38.23 & $4850.0 \mathrm{f}$ & 44.20 \\
\hline $\mathrm{N}_{0} \mathrm{C}_{3}$ & 0 & 9 & $4835.0 \mathrm{ab}$ & 70.53 & $5019.0 \mathrm{de}$ & 49.25 \\
\hline $\mathrm{N}_{1} \mathrm{C}_{0}$ & 100 & 0 & $3585.0 \mathrm{~g}$ & 27.23 & $4377.5 \mathrm{~h}$ & 30.15 \\
\hline $\mathrm{N}_{1} \mathrm{C}_{1}$ & 100 & 3 & $4587.0 \mathrm{c}$ & 61.78 & 4920.0 ef & 46.28 \\
\hline $\mathrm{N}_{1} \mathrm{C}_{2}$ & 100 & 6 & $4797.0 \mathrm{~b}$ & 69.19 & $5172.0 \mathrm{c}$ & 53.78 \\
\hline $\mathrm{N}_{1} \mathrm{C}_{3}$ & 100 & 9 & $4865.0 \mathrm{ab}$ & 71.59 & $5482.5 \mathrm{~b}$ & 63.01 \\
\hline $\mathrm{N}_{2} \mathrm{C}_{0}$ & 150 & 0 & $4370.5 \mathrm{~d}$ & 54.15 & $4637.5 \mathrm{~g}$ & 37.88 \\
\hline $\mathrm{N}_{2} \mathrm{C}_{1}$ & 150 & 3 & $4660.2 \mathrm{c}$ & 64.36 & $5048.2 \mathrm{~d}$ & 50.10 \\
\hline $\mathrm{N}_{2} \mathrm{C}_{2}$ & 150 & 6 & $4870.0 \mathrm{ab}$ & 71.76 & $5445.2 \mathrm{~b}$ & 61.90 \\
\hline $\mathrm{N}_{2} \mathrm{C}_{3}$ & 150 & 9 & $4980.0 \mathrm{a}$ & 75.64 & 5619.2 a & 67.07 \\
\hline
\end{tabular}

Egypt. J. Agron. 33, No. 2 (2011) 


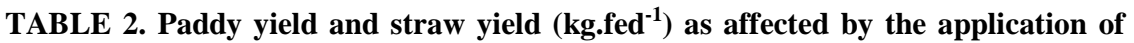
CRS (composted rice straw) and urea in 2008 season.

\begin{tabular}{|l|c|c|c|c|c|c|}
\hline Treatments & $\begin{array}{c}\text { Urea } \\
\text { kg. fed }^{-1}\end{array}$ & $\begin{array}{c}\text { CRS } \\
\text { ton. fed }\end{array}$ & Grains & $\begin{array}{c}\text { \% increase } \\
\text { or decrease }\end{array}$ & Straw & $\begin{array}{c}\text { \% increase } \\
\text { or decrease }\end{array}$ \\
\hline $\mathrm{N}_{0} \mathrm{C}_{0}$ & 0 & 0 & $2800 \mathrm{i}$ & - & $3350 \mathrm{~g}$ & - \\
$\mathrm{N}_{0} \mathrm{C}_{1}$ & 0 & 3 & $3800 \mathrm{~g}$ & 35.71 & $4300 \mathrm{f}$ & 28.35 \\
$\mathrm{~N}_{0} \mathrm{C}_{2}$ & 0 & 6 & $3930 \mathrm{f}$ & 40.35 & $4770 \mathrm{f}$ & 42.38 \\
$\mathrm{~N}_{0} \mathrm{C}_{3}$ & 0 & 9 & $4709 \mathrm{c}$ & 68.17 & $4930 \mathrm{c}$ & 47.16 \\
& 100 & 0 & $3500 \mathrm{~h}$ & 25 & $4257 \mathrm{f}$ & 27.04 \\
$\mathrm{~N}_{1} \mathrm{C}_{0}$ & 100 & 3 & $4600 \mathrm{~d}$ & 64.28 & $4810 \mathrm{~d}$ & 43.58 \\
$\mathrm{~N}_{1} \mathrm{C}_{1}$ & 100 & 6 & $4750 \mathrm{c}$ & 69.64 & $5017 \mathrm{c}$ & 49.76 \\
$\mathrm{~N}_{1} \mathrm{C}_{2}$ & 100 & 9 & $4790 \mathrm{bc}$ & 71.07 & $5213 \mathrm{~b}$ & 55.61 \\
$\mathrm{~N}_{1} \mathrm{C}_{3}$ & 150 & 0 & $4210 \mathrm{e}$ & 50.35 & $4512 \mathrm{e}$ & 34.68 \\
& 150 & 3 & $4740 \mathrm{c}$ & 69.28 & $5000 \mathrm{c}$ & 49.25 \\
$\mathrm{~N}_{2} \mathrm{C}_{0}$ & 150 & 6 & $4850 \mathrm{ab}$ & 73.32 & $5215 \mathrm{~b}$ & 55.67 \\
$\mathrm{~N}_{2} \mathrm{C}_{1}$ & 150 & 9 & $4910 \mathrm{a}$ & 75.35 & $5430 \mathrm{a}$ & 62.08 \\
$\mathrm{~N}_{2} \mathrm{C}_{2}$ & & & & & \\
$\mathrm{~N}_{2} \mathrm{C}_{3}$ & & & & & & \\
\hline
\end{tabular}

It is important to notice that the application of CRS plus urea gave higher grain yield at all combinations treatments than CRS or urea alone. This is likely mainly due to the stimulation of CRS decomposition by the application of $\mathrm{N}$ fertilizer thereby increasing the supply of nitrogen, improving the subsequent recovery by rice plants and therefore increasing the grain yield. These results are consistent with those obtained by Sharma \& Mittra (1991) and Hammad et al. (2006 a). The increase in CRS decomposition might be due to increase in bacterial population. Indeed Jat et al. (2004) found that the incorporation of rice residues increases bacterial population from $50 \times 10^{6}$ to $59 \times 10^{6}$ at 30 and 60 days after sowing, respectively. Data indicate also, that any addition of urea to CRS gave higher grains yield than that observed with CRS alone at the same level but the difference is not always statistically significant. This applies to the difference between $100 \mathrm{~kg}$ urea fed ${ }^{-1}$ and $150 \mathrm{~kg}$ urea fed $^{-1}$ applied both with 6 tons CRS in the second year. The utilization of $150 \mathrm{~kg}$ urea. $\mathrm{fed}^{-1}$ plus 9 tons CRS fed ${ }^{-1}$ gave the highest value of grain yield in both seasons but in the first season if CRS was reduced to 6 tons or when urea was reduced to $100 \mathrm{~kg}$ yields

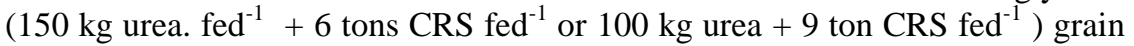
yield did not differ significantly from that maximum yield. In the second season this applied only to the reduction of CRS to 6 tons per fed (no significant difference between maximum yield and yield with $150 \mathrm{~kg}$ urea +6 ton CRS). The straw yield followed an almost similar trend as grains yield but there were some differences. The \% increase due to the treatments is somewhat lesser in straw than in grain. It is clear from our data that, some amount of fertilizer used can be spared by using composted rice straw.

\section{Number of panicles}

Number of panicles per hill (Tables 3 and 4) increased significantly as fertilizer level increased from $0 \mathrm{~kg}$ urea.fed ${ }^{-1}$ without compost rice straw to 9 tons CRS.fed ${ }^{-1}$

Egypt. J. Agron. 33, No. 2 (2011) 
plus $150 \mathrm{~kg}$ urea.fed ${ }^{-1}$. Also, the combination of CRS with urea gave higher number of panicles per hill than CRS or urea alone. This may be due to the decomposition of CRS which release more nutrients to plant as showed by Kalita \& Sharamah (1992) and Begum et al. (2001).

TABLE 3. Yield attributes as affected by the application of CRS (composted rice straw) and urea treatments in 2007 season.

\begin{tabular}{|c|c|c|c|c|c|}
\hline Treatments & $\begin{array}{c}\text { Urea } \\
\text { kg. fed }^{-1}\end{array}$ & $\begin{array}{c}\text { CRS } \\
\text { ton. fed }^{-1}\end{array}$ & $\begin{array}{c}\text { No. of } \\
\text { Panicle. } \\
\text { hill }^{-1}\end{array}$ & $\begin{array}{c}\text { Panicle } \\
\text { length }(\mathbf{c m})\end{array}$ & $\begin{array}{c}\text { 1000 grain } \\
\text { weight }(\mathbf{g})\end{array}$ \\
\hline $\mathrm{N}_{0} \mathrm{C}_{0}$ & 0 & 0 & $14.50 \mathrm{j}$ & $20.65 \mathrm{~d}$ & $19.42 \mathrm{c}$ \\
$\mathrm{N}_{0} \mathrm{C}_{1}$ & 0 & 3 & $20.50 \mathrm{i}$ & $21.92 \mathrm{c}$ & $20.17 \mathrm{abc}$ \\
$\mathrm{N}_{0} \mathrm{C}_{2}$ & 0 & 6 & $22.75 \mathrm{gh}$ & $22.67 \mathrm{a}$ & $20.70 \mathrm{ab}$ \\
$\mathrm{N}_{0} \mathrm{C}_{3}$ & 0 & 9 & $25.25 \mathrm{ef}$ & $22.87 \mathrm{a}$ & $19.85 \mathrm{bc}$ \\
& & & & & \\
$\mathrm{N}_{1} \mathrm{C}_{0}$ & 100 & 0 & $22.25 \mathrm{hi}$ & $21.90 \mathrm{c}$ & $20.52 \mathrm{ab}$ \\
$\mathrm{N}_{1} \mathrm{C}_{1}$ & 100 & 3 & $24.25 \mathrm{fg}$ & $22.35 \mathrm{~b}$ & $20.52 \mathrm{ab}$ \\
$\mathrm{N}_{1} \mathrm{C}_{2}$ & 100 & 6 & $26.50 \mathrm{de}$ & $22.80 \mathrm{a}$ & $20.53 \mathrm{ab}$ \\
$\mathrm{N}_{1} \mathrm{C}_{3}$ & 100 & 9 & $27.75 \mathrm{~cd}$ & $22.85 \mathrm{a}$ & $19.97 \mathrm{abc}$ \\
$\mathrm{N}_{2} \mathrm{C}_{0}$ & 150 & 0 & $27.25 \mathrm{~d}$ & $21.95 \mathrm{c}$ & $20.97 \mathrm{a}$ \\
$\mathrm{N}_{2} \mathrm{C}_{1}$ & 150 & 3 & $29.25 \mathrm{bc}$ & $22.75 \mathrm{a}$ & $20.33 \mathrm{abc}$ \\
$\mathrm{N}_{2} \mathrm{C}_{2}$ & 150 & 6 & $31.00 \mathrm{ab}$ & $22.77 \mathrm{a}$ & $20.47 \mathrm{ab}$ \\
$\mathrm{N}_{2} \mathrm{C}_{3}$ & 150 & 9 & $32.25 \mathrm{a}$ & $22.90 \mathrm{a}$ & $20.05 \mathrm{abc}$ \\
$\mathrm{N}$ & & 9 &
\end{tabular}

TABLE 4. Yield attributes as affected by the application of CRS (composted rice straw) and urea treatments in 2008 season.

\begin{tabular}{|c|c|c|c|c|c|}
\hline Treatments & $\begin{array}{c}\text { Urea } \\
\text { kg. fed }^{-1}\end{array}$ & $\begin{array}{c}\text { CRS } \\
\text { ton. fed }^{\mathbf{1}}\end{array}$ & $\begin{array}{c}\text { No. of } \\
\text { Panicle.hill }^{\mathbf{1}}\end{array}$ & $\begin{array}{c}\text { Panicle } \\
\text { length }(\mathbf{c m})\end{array}$ & $\begin{array}{c}\text { 1000 grain } \\
\text { weight }(\mathbf{g})\end{array}$ \\
\hline $\mathrm{N}_{0} \mathrm{C}_{0}$ & 0 & 0 & $15 \mathrm{~h}$ & $21.23 \mathrm{c}$ & $19.55 \mathrm{c}$ \\
$\mathrm{N}_{0} \mathrm{C}_{1}$ & 0 & 3 & $22 \mathrm{~g}$ & $21.9 \mathrm{abc}$ & $20.86 \mathrm{ab}$ \\
$\mathrm{N}_{0} \mathrm{C}_{2}$ & 0 & 6 & $24 \mathrm{ef}$ & $23 \mathrm{abc}$ & $20.93 \mathrm{a}$ \\
$\mathrm{N}_{0} \mathrm{C}_{3}$ & 0 & 9 & $25.66 \mathrm{de}$ & $23.5 \mathrm{a}$ & $20.26 \mathrm{abc}$ \\
& & & & & \\
$\mathrm{N}_{1} \mathrm{C}_{0}$ & 100 & 0 & $23 \mathrm{fg}$ & $21.43 \mathrm{bc}$ & $20.8 \mathrm{ab}$ \\
$\mathrm{N}_{1} \mathrm{C}_{1}$ & 100 & 3 & $24.66 \mathrm{ef}$ & $22.96 \mathrm{abc}$ & $21 \mathrm{a}$ \\
$\mathrm{N}_{1} \mathrm{C}_{2}$ & 100 & 6 & $26.66 \mathrm{~cd}$ & $23.26 \mathrm{ab}$ & $21.13 \mathrm{a}$ \\
$\mathrm{N}_{1} \mathrm{C}_{3}$ & 100 & 9 & $28.33 \mathrm{c}$ & $22.83 \mathrm{abc}$ & $19.99 \mathrm{bc}$ \\
& & & & & \\
$\mathrm{N}_{2} \mathrm{C}_{0}$ & 150 & 0 & $27.33 \mathrm{~cd}$ & $21.6 \mathrm{bc}$ & $21.06 \mathrm{a}$ \\
$\mathrm{N}_{2} \mathrm{C}_{1}$ & 150 & 3 & $30.66 \mathrm{~b}$ & $22.86 \mathrm{abc}$ & $20.76 \mathrm{ab}$ \\
$\mathrm{N}_{2} \mathrm{C}_{2}$ & 150 & 6 & $31.66 \mathrm{~b}$ & $22.9 \mathrm{abc}$ & $19.99 \mathrm{bc}$ \\
$\mathrm{N}_{2} \mathrm{C}_{3}$ & 150 & 9 & $32.66 \mathrm{a}$ & $23 \mathrm{abc}$ & $20.56 \mathrm{ab}$ \\
\hline
\end{tabular}


Panicle length $(\mathrm{cm})$

Tables 3 and 4 show the effect of CRS, urea treatments and their combinations on panicle length $(\mathrm{cm})$. There are significant increases in panicle length at all treatments as compared with the control. The highest panicle length was attained with the highest applications of CRS (9 tons) plus $100 \mathrm{~kg}_{\text {urea.fed }}{ }^{-1}$ or $150 \mathrm{~kg}$ urea.fed ${ }^{-1}$ but the lowest panicle length was found when no fertilizer added. Panicle length increased with increasing rate of $\mathrm{N}$ fertilizer. Nitrogen increased panicle extrusion and growth in length as reported by Abd ELRahman (1999).

1000 grain weight

Data in Tables 3 and 4 present the effects of treatments on 1000 grain weight $(\mathrm{g})$. There is a slight difference in 1000 grain weight among the different treatments but many means do not differ significantly between them. The slight increase obtained is mainly due to the increase of grains per panicle. As found by Barnes (1985). The highest 1000 grain weight value was recorded at $150 \mathrm{~kg}$ urea. fed $^{-1}$ without compost and $100 \mathrm{~kg}$ urea plus 6 tons CRS in 2007 and 2008, respectively as compared with the control, while the lowest 1000 grains weight value was obtained when no fertilizer was added as also observed by Begum et al. (2001).

Soil organic matter (SOM)

Soil organic matter percentage as affected by the application of composted rice straw (CRS), urea treatments and their combinations are presented in Table 5.

TABLE 5. Soil organic matter (\%) at harvest as affected by the application of CRS (composted rice straw) and urea in 2007 and 2008 seasons.

\begin{tabular}{|c|c|c|c|c|}
\hline Treatments & $\begin{array}{c}\text { Urea } \\
\text { kg. fed }^{-1}\end{array}$ & $\begin{array}{c}\text { CRS } \\
\text { ton. } \text { fed }^{-1}\end{array}$ & $\begin{array}{c}\text { OM (\%) } \\
(2007)\end{array}$ & $\begin{array}{c}\text { OM (\%) } \\
(2008)\end{array}$ \\
\hline $\mathrm{N}_{0} \mathrm{C}_{0}$ & 0 & 0 & $1.40 \mathrm{f}$ & $1.4 \mathrm{~d}$ \\
\hline $\mathrm{N}_{0} \mathrm{C}_{1}$ & 0 & 3 & $1.97 \mathrm{e}$ & $1.83 \mathrm{c}$ \\
\hline $\mathrm{N}_{0} \mathrm{C}_{2}$ & 0 & 6 & $2.15 \mathrm{~cd}$ & $1.99 \mathrm{bc}$ \\
\hline $\mathrm{N}_{0} \mathrm{C}_{3}$ & 0 & 9 & $2.31 \mathrm{ab}$ & $2.00 \mathrm{bc}$ \\
\hline $\mathrm{N}_{1} \mathrm{C}_{0}$ & 100 & 0 & $1.46 \mathrm{f}$ & $1.51 \mathrm{~d}$ \\
\hline $\mathrm{N}_{1} \mathrm{C}_{1}$ & 100 & 3 & $1.99 \mathrm{e}$ & $1.89 \mathrm{c}$ \\
\hline $\mathrm{N}_{1} \mathrm{C}_{2}$ & 100 & 6 & $2.19 \mathrm{bcd}$ & $1.99 \mathrm{bc}$ \\
\hline $\mathrm{N}_{1} \mathrm{C}_{3}$ & 100 & 9 & $2.38 \mathrm{a}$ & $2.00 \mathrm{bc}$ \\
\hline $\mathrm{N}_{2} \mathrm{C}_{0}$ & 150 & 0 & $1.45 \mathrm{f}$ & $1.51 \mathrm{~d}$ \\
\hline $\mathrm{N}_{2} \mathrm{C}_{1}$ & 150 & 3 & $2.05 \mathrm{de}$ & $1.96 \mathrm{~b}$ \\
\hline $\mathrm{N}_{2} \mathrm{C}_{2}$ & 150 & 6 & $2.23 \mathrm{bc}$ & $2.11 \mathrm{ab}$ \\
\hline $\mathrm{N}_{2} \mathrm{C}_{3}$ & 150 & 9 & $2.41 \mathrm{a}$ & $2.23 \mathrm{a}$ \\
\hline
\end{tabular}

Egypt. J. Agron. 33, No. 2 (2011) 
The percentage of soil organic matter increased with increasing amount of CRS either applied alone or in combinations with different levels of urea as compared with the control at harvest. These results are consistent with those obtained by Hammad et al. (1998), Awad (2001) and El-Kouny et al. (2004) who indicated that soil organic matter content increased by adding organic fertilizer or using compost.

The highest values of SOM were recorded with the combinations of urea at $150 \mathrm{~kg} . \mathrm{fed}^{-1}$ plus the rate of 9 tons CRS.fed ${ }^{-1}$ at harvest stage. That correspond to the treatment giving the highest yield. Charkrabarti et al. (2003) found similar results with integrated applications of organic and inorganic fertilizers. Inorganic fertilizers may meet the demand of mineral nutrition by microbes but cannot provide carbon, which is a major constituent of microbial cells. Integrated applications of organic and inorganic materials provide balanced mineral nutrition as well as carbon.

\section{Regression analysis}

Multiple linear regressions from the following formula illustrated that organic matter had a role in predicting the grain yield $(\mathrm{y})\left(\mathrm{R}^{2}=60 \%\right.$ and the adj. $\mathrm{R}^{2}=56 \%$ in 2007 and $\mathrm{R}-\mathrm{Sq}=68.6 \%$ and $\mathrm{R}-\mathrm{Sq}(\operatorname{adj})=65.4 \%$ in 2008$)$.

Therefore, the expected equation to predict the grain yield is as follows: Grain yield $=1520+1411$ Organic matter $(2007)$ Grain yield $=337+2120$ Organic matter (2008).

\section{Polynomial regression}

As illustrated in Fig. 1 and 2 the computed quadratic regression equation for predicting grain yield $(\mathrm{y})$ was the following:

$\mathrm{Y}=2330.07+513.150 \mathrm{X}+239.114 \mathrm{X} * 2$

$\mathrm{R}-\mathrm{Sq}=60.2 \%(2007)$

$\mathrm{Y}=-3708.41+6755.52 \mathrm{X}-1298.89 \mathrm{X}^{* * 2}$

$\mathrm{R}-\mathrm{Sq}=69.8 \%(2008)$

(where $\mathrm{X}=$ Organic matter)

The regression analysis confirms that organic matter had a significant effect on grain yield under the conditions of this study.

\section{Conclusion}

Under the conditions of this study we can concluded that. The combined use of composted rice straw and urea resulted in grain yield advantage and improvement in soil organic matter as compared to urea alone especially, both $150 \mathrm{~kg}$ urea. $\mathrm{fed}^{-1}+6$ tons CRS fed ${ }^{-1}$ or $100 \mathrm{~kg}$ urea +9 ton CRS fed $^{-1}$ in both seasons. 


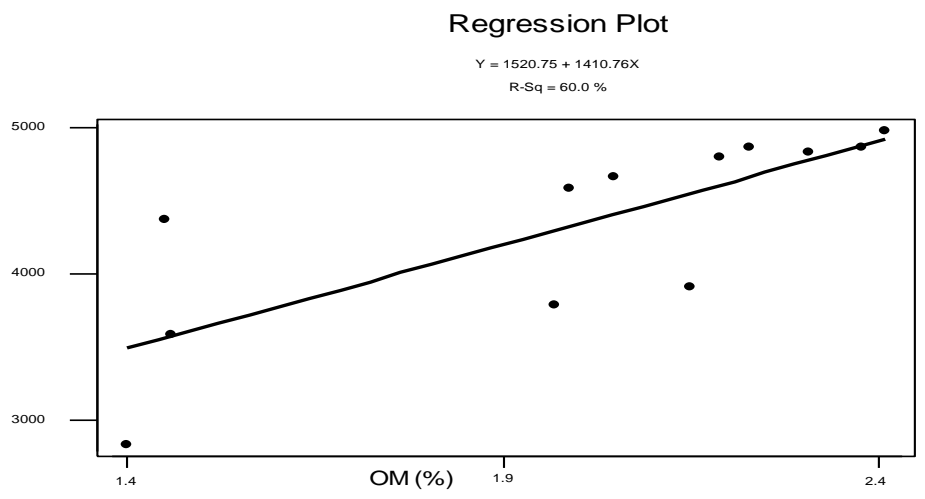

Fig.1. Simple regression coefficient between grain yield and organic matter as affected by different treatments in 2007 season.



Fig.2. Simple regression coefficient between grain yield and organic matter as affected by different treatments in 2008 season.

\section{References}

Abd El-Rahman, A. A. M. (1999) Performance of some rice varieties as influenced by different nitrogen levels under salt affected soil. Egypt, J. Agric. Res. 77 (2), 713 - 720.

Awad, M.Y.M. (2001) Effect of some organic compounds on soil properties and plant growth. M.Sc.Thesis, Fac. of Agric. Minufiya. Univ., Egypt.

Barnes, J.E. (1985) The response of rice to time and rate of application of nitrogen in burdexin valley. Queensland Jour of Agric and Anion Sci. 42 (2), 71-77.

Begum, S., Rhman, M.M., Abdin Main, M.J., Islam, M.R. and Uddin, M. (2001) Effect of nitrogen supplied from manure and fertilizer on the growth, yield and nutrient uptake of rice. Online Journal of Biological Sciences, 1 (18), 708-710.

Charkrabarti, K., Bhattch Arryya and Charkraborty, A. (2003) Effect of metal contaminated organic wastes on microbial biomass and activites. In: "Heavy Metals Egypt. J. Agron. 33, No. 2 (2011) 
Contamination of Soil”. Ahmed,I; S.Hayat and J.Pichet (Ed). Ball State University . Natural Resources and Environmental Management Muncie, IN. USA.A.C 386206.

Cottenie, A., Camerbynck, R., Verloo, M. and Dhaere, A. (1979) Fractionation and determination of trace elements in plants. Soils and Sediments. Pure Appl. Chem. $\mathbf{5 2 , 1 4 5 - 1 5 3 . ~}$

El-Kouny, H.M., El- Assar, A.M. and Mohamed, S.G. (2004) Effectivness of natural organic amendments, biologically actived compost, and mineral fertilization sources of potassium in improving soil properties and productivity of Zaghlow CV. data plam in calcareous soil. Assuite.J.Agric. 35 (2),195-214.

Gomaz, K.H. and Gomaz, A.A. (1984) "Statical Procedures for Agricultural Research". Inc.New York.

Hammad, S.A., EL-Hamdi, K.H., Ghanem, S.A. and Naeem, E.S. (2006a) Grain yield of lowland (Oriza sativa) as influenced by integrated use of urea and rice straw fertilizer. J.Agric. Sci. Mansoura Univ. 31(6), 3993-3999.

Hammad, S.A., El-Agrodi, W.M., El-Mallah, M.I. and Adel, M.A. (1998) Phosphorous status of representative soil soil profiles in Dakahlia Governorate. J. Agric. Mansoura Univ. 23 (7), 3448- 3516.

Jat, M.L., Pal, S.S., Shukla, L., Mathur, J. and Singh, M. (2004) Rice (Oriza sativa) residue management using cellulolytic fungi and its effect on wheat (Triticum aestivum) yield and soil health in rice wheat cropping system. J. Agric. Sci. 74 (3), 117-120.

Kalita, M.C. and Sharamah, N.N. (1992) Effect of nitrogen level and mulch on yield and yield attributing characters of summer rice under the rainfed condition. Ind. J. Agron. 37 (4), 690-693.

Page, A. L., Miller, R.H. and Keeney, D.R. (1982) "Methods of Soil Analysis" - part 2. Amer. Sco. Agric. Inc. Madison.

Sharma, A.R. and Mittra, B.N. (1991) Effect of different rates of application of organic and nitrogen fertilizers in rice-based cropping system. J.Agric.Sci. 117 (3), 313-318.

Singha, D.D. (2003) Management of crop residues in summer rice and its effect on the soil properties and crop yield. Crop-Ress. Hisar. 25 (1), 191-193.

(Received 21/8/2011;

accepted 8/ 12/2011) 


\section{تأثير إضافة السماد العضوي على إنتاجية محصول الحبوب لصنف

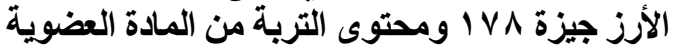



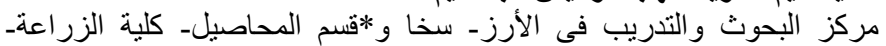

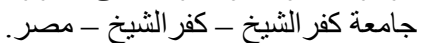

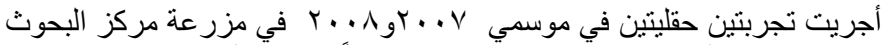

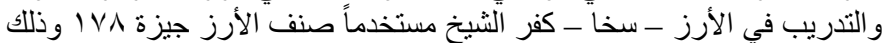

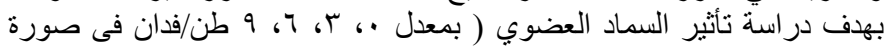

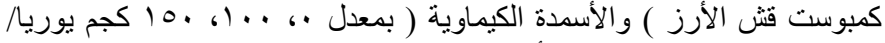

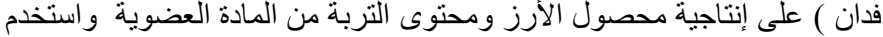

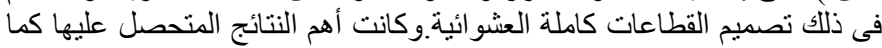

أظهرت النتائج أن أعلى محصول للحبوب ظهر عند استخدام 9 طن من سماد

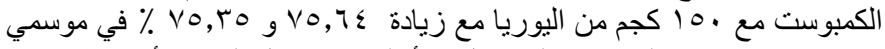

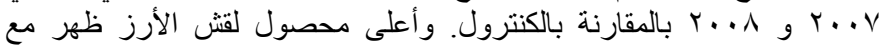

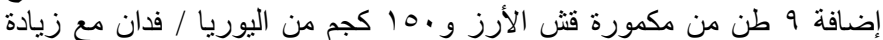

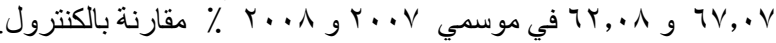

لوحظ وجود اختلافات طفيفة في وزن الألف حبة بين المعاملات المختلفة.

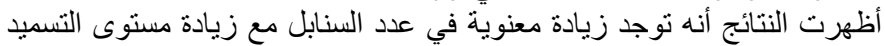

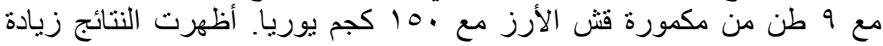

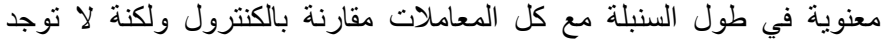

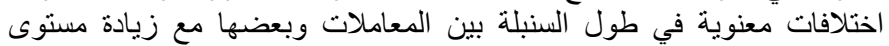

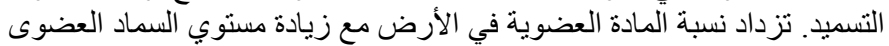

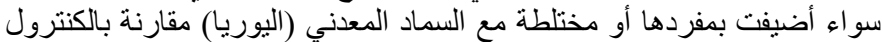

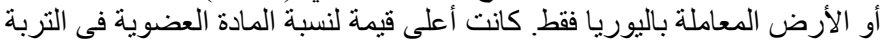

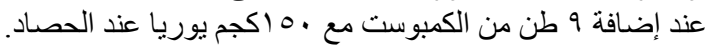

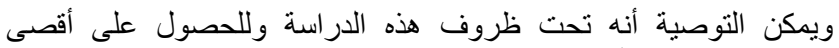



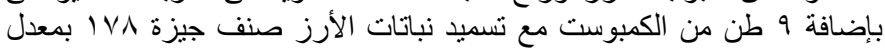

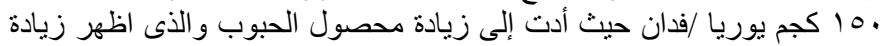

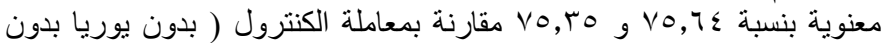

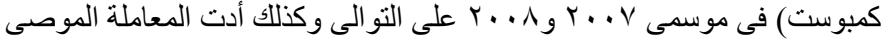

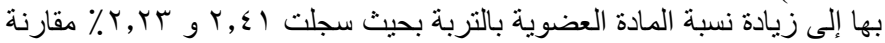


التو الي. 